\title{
Economic Policy, Does it Help Life Expectancy? An African Evidence on the Role of Economic Policy on Longevity
}

\author{
Paul Ojeaga, PhD \\ University of Bergamo, \\ Research Scholar Bentley University Boston 2011 to 2012 \\ Email: paul.ojeaga@unibg.it
}

\section{Doi:10.5901/ajis.2014.v3n4p445}

\begin{abstract}
We evaluate the factors that affect longevity in Africa, with the aim of offering an insight on how government economic policy and consumption spending affect the lives of people in developing countries. Government economic policy was found to be contributing in a negative manner to life expectancy in the countries in our sample. We also find that apathy between the civil service (the embodiment of institutions) and political office holders to be the greatest stumbling block against the success of governmental economic policy, this creates a hole in institutions since they remain the pipe through which revenue is disbursed and policies are implemented for the general good of the populace. After interacting institution with economic policy we find that economic policy has significant effect on life expectancy it was likely that institutions were either circumvented or ignored, leading to possible short comings on the overall effect that government economic policy would have had on life expectancy.
\end{abstract}

Keywords: Corruption, life expectancy, institutional quality, government spending, industrialization

\section{Introduction}

Africa is plagued by a lot of diseases, social strife and civil wars, that are otherwise preventable. Malaria fever according World Health Organization report 2010 was responsible for about 655000 deaths in Africa in 2010 alone. Africa's has a high population living below the poverty line, this makes it one of the poorest continents in the world past literature state that the average per capita income in sub-Saharan Africa is less than one-twentieth that of North America (Acemoglu D et al (2002) and Acemoglu (2004)). This paper ${ }^{1}$ addresses the impact of economic policy on longevity. According to United Nations statistics 2010,the average life expectancy in sub Saharan Africa is between 31.88 years for very poor countries like Swaziland to about 60.1 for middle income African countries like Ghana, with only very few people having access to public benefits (government fund). Some basic reasons for this are the lack of viable markets for domestic trade, its high amount of poorly educated people, and finally the presence of old and outdated machineries which are nonexistent in some instances for its manufacturing industry (Acemoglu D. et al (2002)). However these are just some theoretical and secondary reasons for under development in Africa ${ }^{2}$. The primary reason for underdevelopment in Africa continues to lie on the foundation upon which the present method of governance is built. Most of the institutions of governance were developed during the colonial era and where meant to serve the purpose of the colonial governments therefore they were not well suited to meet indigenous societal circumstances, since most of the colonies were used as raw material exporting economies particularly in tropical regions. This meant that institutions were apparently weak and unreliable.

The aim of this study is to examine the effect of government economic policy on life expectancy in Africa. We identify problems that could affect life expectancy on the short run, as short term pay out used to dose civil agitations such as political unrest and civil strikes as likely factors that is unobservable overtime, since these kind of agitations many a times forces governments to make humane decisions, and are likely to be correlated with life expectancy on the short run, we expect this to be reflected in government consumption spending. This makes us divide government economic

\footnotetext{
1 I am grateful to Bergamo University Department of Economics for providing funds for this research.

${ }^{2}$ Acemoglu, Johnson and Robinson (2002) examine the differences in European death rates in order to estimate the effect of institutions, on economic performance. Europeans were noticed to have adopted very different colonization policies in different colonies with rest to its geographical position, with different associated institutions.
} 
decisions into two spheres which are its monetary and trade policies which we call its economic policy on one hand, and it policies regarding social spending which we call government consumption spending on the other. The reason for this is that it is likely that government spending will contribute positively to longevity, but we do not expect their monetary and trade policy to contribute to longevity in a positive manner particularly in developing countries with weak institutions, since institutions can weaken government policies if they are ineffective or bypassed. Secondly we also wish to determine the extent to which government consumption spending (its fiscal policy component) cushions factors that are a risk to longevity in Africa. We use panel data and two stage least squares (2SLS) instrumental variable approach to address the problem of endogeneity since government economic policy and its fiscal spending are likely to suffer from measurement problems. The rest of this paper is divided into five sections, constraints to longevity in Africa, some theory, data description, and empirical analysis and finally the concluding sections.

\section{Literature Review}

Africa's huge deposits of untapped natural resource also contributes to its burden, it makes it highly susceptible to corruption. Past studies also show that countries endowed with high levels of natural resources do tend to grow more slowly compared to those with little or no resource (see Sachs and Warner, 1995), and growth could also be weakened if institutional frameworks are weak (see Mehlum et al, 2006) ? $^{3}$. The presence of natural resource in developing countries therefore plays a role in weakening institutions in developing countries, since it provides government with alternative revenue to run government, preventing it from setting up effective taxation mechanism for sustainable revenue generation (see Ross 2001). Institutional weakness is also prevalent today among African countries because of the gross neglect of the civil service and due process in policy implementation, government can for example rely on its revenues from natural resource to repress dissent, either through paying off opposition (by awarding them contracts in high profile infrastructure projects) resulting to weakening of the civil service or governing through violence and intimidation. Corruption can also lead to failure of democratic governments in developing countries since this can have adverse effect on growth and internal stability (Karl, 1997; Ross, 2001)4. The weaknesses in the internal structures of developing countries often give room to corrupt officials to run government policies in a vague manner or to lead the populace in these developing countries in complete secrecy. Through the implementation of weak economic policies an oligarch class often emerges that rules with impunity and become gradually insensitive to the plight of the populace. The effective use of institutions for governance in conjunction with a reliable civil service structure can help rectify this problem. Institutions can be classified into different categories such as judicial institutions, democratic institutions, and economic institutions.

Life expectancy can have serious effects on productivity in developing countries. Past literature has discussed the relation between longevity and growth in a host of industrialized countries. Barro (1989) discovered that as the life expectancy of a country rises to the age of 69 , the level of investment and the growth rate increased in a reasonable manner for many developed countries; but in cases where life expectancy rises to the age of 70 and beyond, the level of investment and the growth rate drops, this was higher for developed countries compared to developing countries. ${ }^{5}$ (See Lee, Zhang and Zhang (2002) for more explanations). Other papers have investigated the impact that population aging has on growth Auerbach and Kotlikoff (1992), found that population aging has a possible adverse impact on national savings, while Preston (1987) found that aging increases the competition for resources between the consumption and health needs of old people and the investment in children. Attaining old age also means that inheritance could likely be received by the children of such elderly people, who will likely pass on their wealth to their offspring, and the amount of such inheritance may be reduced however by longer years of consumption by the elderly due to sickness or possible periods of inactivity see Kalemi-Ozcan (2002) and Soares (2005). Kelley and Schmidt (1995) ${ }^{6}$ found a positive effect, in

\footnotetext{
${ }^{3}$ Mehlum, Moene and Torvik (2006) also explain how institutions are weakened by the presences of natural resources through corruption and the scramble for allocation of exploration rights thereby limiting growth in resource rich countries.

${ }^{4}$ Michael Ross (2001) in "Extractive Sectors and the Poor" explains the link between corruption and mineral extraction and how democracies are likely to fail due to foreign interest and institutional weakness in resource rich developing countries. He finds that the scramble for power is often associated with the presence of natural resources in many developing countries.

${ }^{5}$ Barro(1989) using a cross-section of countries, found that investment ratio and growth increased for developed countries with life expectancy of up to 69 years, but as life expectancy increased beyond 70 years growth rate decreased and investment reduced considerably.

${ }^{6}$ Kelly and Schmidt (1995) in "Aggregate Population and Economic Growth Correlation: The Role of The Component of Demographic Change" found that longevity has a positive significant effect on growth. The implication of their study is that cushioning factors that 
the reduction in death rates, on growth in less developed countries suggesting that longevity drives growth in a number of countries. Acemoglu and Johnson (2007) also find a slight positive effect of life expectancy on growth but state that life expectancy does not affect income.

\section{Constraints to Longevity in Africa}

Several factors work together to increase mortality rate in developing countries and sub Saharan Africa in particular. Some of these include infectious tropical diseases that often affect their marginalized population due to poor education, lack of social awareness, political instability and civil strife. Infectious tropical diseases are often a major cause of high death rate prevalent in many sub Saharan African countries since most of the people in sub Saharan Africa live below the poverty line, therefore the tendency for disease to spread and patients to die as a result of inability to afford medical treatment is high. Cholera for instance, according to the World Health Organization report 2010 caused about 130000 deaths with over 2.5 million infected worldwide. In Africa alone according to United Nations Children Emergency Fund (UNICEF) report 2011 more than 85000 cases of cholera infection has been recorded with a 4.7 percent mortality rate. Other diseases such as Human Immuno Virus (HIV), responsible for Acquired Immune Deficiency Syndrome disease (AIDS) for instance is a major cause of death in sub Saharan Africa. Sub Saharan Africa according to 2009 United Nations Statistics also accounts for about $65 \%$ of HIV AIDS infected people and about $75 \%$ of all deaths associated with HIV AIDS Worldwide. While malaria fever, polio, tuberculosis etc are widely responsible for a high amount of death among Africa's population. Government economic policies if favorable can empower people through employment, to afford access to health care and decent living which can prevent premature death.

Social factors such as poor education and lack of information regarding treatment and preventive methods that could be useful in avoiding the risk of infection are also lacking, poor literacy rate makes it cumbersome to pass on such information to the populace. UNESCO World education regional review of year 2000 showed that only about $52 \%$ of the children in sub-Saharan Africa were enrolled in primary schools, this was the lowest anywhere in the World. Africa also recorded the highest number of children deprived of basic education according to Transparency International World report of 2010 conducted among 8500 educators in seven countries. Africa continues to account for the highest amount of illiterate adults worldwide and has one of the lowest school enrollment rates. Preventing major illness and other factors that can lead to early deaths can many a time hinge on early detection and prevention which can be achieved better in a more literate and socially aware society. Good information can help eradicate poor religious practices, outdated customary traditional rites and beliefs that are a risk to longevity such as female genital mutilation which can in some instance lead to death through female circumcision infections. Poverty and unemployment is also rampant among the population, this often makes a large section of the population to be vulnerable since in some instances they are likely not to be able to afford access to basic social amenities.

Political factors such as instability and civil strife can in some cases lead to civil war and a high degree of uncertainty. This can make government to fail leading to a disruption in daily life. This in turn can affect economic activities and cause a lot of suffering due to shortages of basic supplies, which if exist for a prolonged period of time can lead to poor living standard and outbreak of epidemics. Some examples of political factors that can increase mortality rates are civil wars, civil disturbances, ethnic cleansing and ethnic clashes. The second Congo civil war of 1998 to 2003 according to United Nations 2004 Statistics is recorded among the deadliest African civil wars in modern history, with the war alone responsible for as many as 5.4 million people killed from the war, with most deaths as a result of the underlying effects of the war particularly starvation. Institutional weakness within the body polity of a country can also be responsible for most political factors related deaths since good institutions can prevent a systematic breakdown of the governing authority thereby preventing a gradual drift into anarchy.

\section{Theory and Methodology}

We present a simple theory to depict how governmental policy will interplay with other interaction within and outside a system in shaping the life expectancy or longevity of people living within a specified geographical location. Our theoretical model is such that a change in life expectancy depends on the change in government economic policy and its interaction 
with other country specific factors and exogenous variables that affect life expectancy. The change in life expectancy with respect to changes in government specific economic policy will depend upon other interactions, such as other factor within the system such as wages (w) which represents the relative individual income that allows the citizenry to access the basic provisions within a system with an intent of living a comfortable life, the cost of capital (v) which depicts the cost of maintaining and providing social amenities, the quality of institutions (I) through which these policies are implemented and other exogenous variables (z). The model suggests that it is the factors that affect life expectancy in general that determine how long an individual within any given system will live. So government will tend to maximize their policy subject to the constraints that limit or improve how effective economic policies can produce the desired effects in improving longevity.

If we consider the countries to be firms whose cost are functions of several factors. These include the cost of labor $(\mathrm{w})$, the cost of capital $(\mathrm{v})$ in executing socio economic projects, day to day costs of running institutions (I), and some other form of social or economic interest (z). The cost of labor is the wage rate per unit of output produced. The cost of capital can be viewed as the typical rental price of capital but also more broadly as to include additional factors impacting the cost of obtaining capital such as access to credit. Running costs are a function of provision of basic amenities such as health care and more importantly other forms infrastructure, while the cost of maintaining an international status and ideology of some form can be viewed a form of social or national interest that can attract investment or international confidence by portraying the presence of stability in a country to shore up investor confidence. So, the firms total cost function can be written as $T C_{i}=f_{i}(w, v, I, z) X_{i}$. The marginal cost (MC) can be expressed as $f_{i}(w, v, I, z)$. as firms' investment in human capital increase we expect an increase in output leading to some level of prosperity thereby improving longevity. We can assume that eventually scarcities will occur and the marginal cost of production will rise. This can occur because of the rising cost of investing in an additional citizen and/or because of increase in capital costs of maintaining a citizen is rising. Eventually, there reaches a point at which equilibrium occurs in the sector. This profit maximization point $\left(X_{i}^{*}\right)$ will represent the point at which $M R_{i}=M C_{i}$, also expressed as $P_{i}=f_{i}(w, v, I, z)$ where the cost in maintaining a citizen or catering for an additional citizen will equal the output that such a citizen will produce on the long run. One of the goals of government economic policy $\left(p_{i}\right)$ is to improve living conditions of the citizens in their countries. There are many ways in which this can occur. Government economic policy can increase education and training of workers, which would lower the firms labor cost per unit produced. So, the wage cost per unit produced can be expressed as a negative function of economic policy $w_{i}\left(p_{i}\right)$. Economic policy may also subsidize social amenities for citizens or come in the form of provisions of schools or product subsidy like petrol or gas used for individuals and households. Therefore, we can write the cost of capital as a negative function of government economic policy, $v_{i}\left(p_{i}\right)$. The availability of wealth to a country may also lead to the promotion of a social status for a country with it might come some form of rent seeking behavior of government officials since more funds flowing into ideological projects may end up been diverted by corrupt officials seeking higher payout and have a spillover effect on the quality of institutions. Therefore, the costs imposed by rent seeking officials are modeled as a positive function of government economic policy, $z_{i}\left(p_{i}\right)$. with policy included in the model we can rewrite the equilibrium condition as $\sigma_{i}=f_{i}\left[w_{i}\left(p_{i}\right), v_{i}\left(p_{i}\right), I_{i}\left(p_{i}\right) Z_{i}\left(p_{i}\right)\right]$.

We can now examine the impact of the equilibrium condition from a change in economic policy. We will assume that economic policy does not impact output; therefore, the differentiation of this condition with respect to economic policy is only a differentiation of the marginal cost function. This can be expressed as shown below.

(1.) $\frac{\partial l_{i}}{\partial p_{i}}=\frac{\partial l_{i}}{\partial w_{i}} \frac{\partial w_{i}}{\partial p_{i}}+\frac{\partial l_{i}}{\partial v_{i}} \frac{\partial v_{i}}{\partial p_{i}}+\frac{\partial l_{i}}{\partial I_{i}} \frac{\partial I_{i}}{\partial p_{i}}+\frac{\partial l_{i}}{\partial z_{i}} \frac{\partial \mathrm{z}}{\partial p_{i}}$

first expression on the right hand side $\left(\frac{\partial l_{i}}{\partial w_{i}} \frac{\partial w_{i}}{\partial p_{i}} \leq 0\right)$ represents government economic policy potentially lowering the cost of labor. The scenario where government economic policy potentially lowers cost of capital is represented as $\frac{\partial l_{i}}{\partial v_{i}} \frac{\partial v_{i}}{\partial p_{i}} \leq 0$. The potential reduction in costs of running institutions is shown as $\frac{\partial l_{i}}{\partial I_{i}} \frac{\partial I_{i}}{\partial p_{i}} \leq 0$. The possible rise in rent seeking or other socio economic interest costs of some sorts is the last term on the right hand side which is $\frac{\partial l_{i}}{\partial z_{i}} \frac{\partial z_{i}}{\partial p_{i}} \geq 0$. Therefore, the overall impact of government economic policy is combining three potential cost reduction factors ( $(\mathrm{v}, \mathrm{v}, \mathrm{I}$, ) with one potential cost increase $(\mathrm{z})$. Whether or not the overall sign of $\frac{\partial l_{i}}{\partial p_{i}}$ is greater or less than zero will depend to a large extent on the quality of a country's institutions and on how the government economic policy is directed. If government economic policy is directed towards more productive uses that lower ' labor, capital and/or institutional costs of providing basic social amenities then this will help turn the prediction towards lower marginal costs. If marginal costs of providing basic social amenities fall for countries as a result of effective government economic policy devoid of corruption, 
then life expectancy will increase. In other words, if $\frac{\partial l_{i}}{\partial p_{i}}<0$ and $\frac{\partial x_{i}}{\partial p_{i}}>0$. We estimate two variants of our life expectancy equation in equation 2 and 3 below, where we capture the cost of capital using country specific income, the percent of people who earn wages with the total labor market participation rate and institution using an index for the quality of institutions. Our model present a case where life expectancy (Life. $\left.\exp _{i t}\right)$ is a function of, government economic policy ( policy $_{i, t}$ ), and our vector of exogenous effects that affect life expectancy $X_{i t}$. Our list of exogenous variables in equation 2, consist of, income (GDP per capita) the quality of institutions which captures the effectiveness of institutions in executing government policies and bringing its

(2.) Life. $\exp _{i t}=\beta_{0}+\beta_{1} X_{i, t}+\beta_{2}$ policy $_{i, t}+\varepsilon_{i t}$

(3. ) Life. $\exp _{i t}=\beta_{0}+\beta_{1} X_{i, t}+\beta_{2}$ Gov.Spending $i, t+\varepsilon_{i t}$

impact close to the grassroots, labor market participation rate which reflects the percentage of the population that can access basic facilities (since they are not free) through been empowered by some form of employment, foreign aid since most African countries receive foreign aid, access to basic health care which reflects how easy it is for the population living within a country to access basic health services to reduce risk of death related to infections and diseases, access to basic clean drinking water which captures the availability of social amenities, country specific total population which puts a strain on the budget of a country depending on how populated a country is although we use the logarithm of population in our final analysis due to scaling issues in our estimates. We separate our fiscal variables from what we call government economic policy so as to allow us differentiate the difference of the impact of government monetary and trade policy from its fiscal policy. The reason for this is that government consumption spending is likely to have a strong effect on life expectancy therefore investigating its effect on life expectancy will allows us know the extent to which government welfare spending in African countries affect life expectancy. We rewrite equation 2 to depict the effect of government consumption spending Gov. Spending $g_{i, t}$ on life expectancy in equation 3 as shown above. We present below the hypothesis that we wish to test in this study. Finally we interact economic policy with institutions to determine the effect of institutions on economic policy effectiveness. We rewrite equation 2 below as equation 2 !"

(2! .) Life. $\exp =\beta_{0}+\beta_{1} X_{i, t}+\beta_{2}$ polıc $_{i, t}+\beta_{3}$ interact $_{i, t}+\varepsilon_{i t}$

Where interact $=$ economic policy*institutional quality

We present below the hypothesis that we wish to test in this paper as follows,

- Hypothesis \#1.) Government Economic policy (it's monetary and trade policy) can have either a positive effect or negative effect on life expectancy due to poor institutions.

- Hypothesis \#2.) Government Consumption spending (government fiscal policy) will have a positive effect on life expectancy due to high prevalence of diseases and shortages of social amenities in Africa.

- Hypothesis \#3.) Economic policy will have a positive effect on life expectancy if institutions are taken into consideration in executing such policies.

\section{Data and Sources}

We present a summary of all variables used below. We obtain data for five countries in Africa, four in sub Saharan Africa and one in North Africa (i.e. Kenya, Botswana, Ghana Cameroon and Egypt) for a period of 1980 to 2008 although some are missing.

\subsection{Description of Dependent Variable}

Our dependent variable life expectancy is obtained from World development indicator data of the World Bank; life expectancy is defined as the average life span for men and women living within any specified geographical location. It depicts the average mortality rate for men and women by country. In most cases it is calculated separately for men and women due to the difference in probability of dying. Many factors affect life expectancy such as infant mortality rates and geographical location since some diseases are likely to thrive in some areas of the world than others. Life expectancy is therefore calculated as the average probability of surviving based on age, sex, geographical location etc therefore it is defined as an arithmetic mean calculated by integrating the survival curve from age 0 to positive infinity.

\subsection{Description of Government Economic Policy and Institutional quality indices}

We construct government economic policy index using principal component analysis (PCA). We use data that depict 
government monetary (inflation) trade (trade openness) and fiscal(government spending )policies to capture the variation in economic policy, based on past literature e.g. Burnside and Dollar (2000), and Elbers et al (2001) that have previously used regression component approach to generate indices. Having a single index for economic policy

Table 1. Descriptive statistics

\begin{tabular}{|c|c|c|c|c|c|}
\hline & Observation & Mean & Std.Dev. & Min & $\operatorname{Max}$ \\
\hline Life expectancy & 195 & 55.04 & 5.11 & 44.63 & 68.41 \\
\hline logarithm of GDP per Capita & 195 & 13.36 & 0.84 & 11.87 & 15.79 \\
\hline Foreign Aid/GDP & 104 & 4.39 & 2.98 & 0.77 & 16 \\
\hline Health Access & 141 & 73.33 & 22.62 & 5 & 99 \\
\hline Population & 195 & 2.1 & 1.92 & 0.06 & 7.73 \\
\hline Labor Market Participation Rate & 145 & 68.8 & 10.95 & 47.8 & 82.4 \\
\hline Water Access & 195 & 48.1 & 28.93 & 2 & 97 \\
\hline School Enrollment Rate (0-15years) & 183 & 88.94 & 15.64 & 55.15 & 119.87 \\
\hline Torture Rate & 140 & 0.59 & 0.61 & 0 & 2 \\
\hline Electoral Self Determination Rate & 140 & 0.99 & 0.73 & 0 & 2 \\
\hline Ethnic Fractionalization Rate & 195 & 83 & 78.13 & 8 & 230 \\
\hline Political Imprisonment & 140 & 0.87 & 0.83 & 0 & 2 \\
\hline Government Economic Policy Index & 143 & 50.36 & 1.19 & 48.52 & 53.68 \\
\hline Institutional Quality Index & 140 & 78.81 & 1.9 & 74.65 & 81.17 \\
\hline Government Consumption Spending & 143 & 3.85 & 42.63 & 0.01 & 510 \\
\hline Market Capitalization Rate & 78 & 1.01 & 2.32 & 0.01 & 14 \\
\hline Foreign Direct Investment & 171 & 1.67 & 2.6 & -10.782 & 15.59 \\
\hline Inflation & 190 & 15.05 & 17.4 & -3.21 & 122.63 \\
\hline Openness & 195 & 70.24 & 30.56 & 22.25 & 157.625 \\
\hline Crude Oil Prices & 195 & 42.72 & 21.48 & 15.93 & 99.11 \\
\hline
\end{tabular}

allows us to discuss the effect of economic policy as a whole on life expectancy instead of enumerating the individual effect of the different economic policy variables. Inflation is the increase in the price of goods and services in a country over a period of time; we obtain this from World Bank data. While openness is given as exports plus import divided by gross domestic product (GDP) this captures country specific trade policy we obtain this data from Penn World Tables both for a period of 1980 to 2008. We dropped our fiscal variable government consumption spending to explore the effect of government monetary and trade decisions on life expectancy independent of our fiscal variable, government consumption spending has the tendency to alleviate poverty and cushion the effect of factors that can affect longevity, this allows us to evaluate the difference in the effect of government consumption spending on life expectancy differently.

\subsection{Other explanatory variables}

Other data used include population which represents the number of people living per geographical square kilometer per country, but we take the logarithm of population to resolve issues of scaling so as to have our estimates in three decimal places, access to healthcare, labor market participation rate, school enrollment rate and foreign aid. Labor market participation represents the percentage of the working population that participates in a country job market, while school enrollment is the percentage of children from 0-15 years that are enrolled in schools this reflects the level of social awareness and enlightenment present in a country. Our data for foreign aid captures total flow of official aid to countries (bilateral plus multilateral aid) we include aid because aid consists of a reasonable percentage of the GDP of most developing countries. We use market capitalization to capture the effect of organized domestic trade on life expectancy since the capital market often acts as a way of saving or investing money for the future, while foreign direct investment captures the effect of inflow of foreign investment and international trade on life expectancy. We capture country specific cost of living using transportation cost represented as the cost of crude oil price to reflect the impact that country specific cost of living has on life expectancy. We obtained also the percentage immunization for children between the ages of 0 to 15 years of age to capture country specific access to medical (or health) care, while the percentage of the population that had access to good drinking water was used to capture the level of provision of basic social amenities. Finally we obtain data on government spending form data market of Iceland., all data are obtained from the World bank data for a period of 1980 to 2008, except otherwise stated. 


\section{Empirical Analysis and Results}

We estimate three variants of life expectancy equations as shown in the equations 4 to 9 below. Our assertion is that government decisions is of two forms one that deals with its monetary and trade decisions (which we call economic policy) and the other that captures its public spending (which we call government spending). It is reasonable that they should have an impact on life expectancy in a different manner with government consumption spending have much more capability in reducing mortality rate due to its direct focus on welfare projects and depending on the level of implementation of government policies which could either have a positive result or otherwise. If the aim of government is to make life relatively comfortable for its citizens, we expect that government economic and social decisions will be one that mitigates risk associated with mortality rate and alleviates poverty through employment. Hausman specification test was run to choose between fixed and random effects. Results accept the null hypothesis that the fixed effects estimator is not biased ( $p$-values are all considerably lower than .01) for the two variants of our life expectancy equation. The use of instrumental variables approach is because of the endogeneity of the economic policy and government consumption spending variables since they are likely to suffer from measurement problems. A Hausman-Wu test rejected the null hypothesis that economic policy and government spending were exogenous, with a $p$-value of 0.00 . Therefore, using them as independent variables could lead to biased results. We use instruments as proxy for both government policy and consumption spending and assume that they are endogenous. We present three variants of our life expectancy equation below to explain how economic policy and consumption spending affects life expectancy.

\subsection{Life Expectancy Model Specification with Economic Policy}

In the first variant of the life expectancy, in equation 5 life expectancy depends on economic policy and our vector of exogenous $X_{i, t}$ which consist of foreign aid, access to health

(4.) Policy $_{i t}=\alpha_{0}+\alpha_{1} X_{i t}+\alpha_{2} Z_{i t}+c_{i}+\mu_{i t}$

(5.) Life. $\exp _{i t}=\beta_{0}+\beta_{1} X_{i, t}+\beta_{2} \widehat{\text { Pollc }} y_{i, t}+c_{i}+\mu_{i t}$

care, the logarithm of income (GDP per capita), the quality of institutions, access to water (which capture provision of basic social amenities), country specific population, labor market participation rate, cost of living and school enrollment rate. Life expectancy therefore is expected to be affected by the rate at which government responds to economic factors that are likely to increase mortality rate. Hyper inflation for example could mean firms closing down and laying off workers and adverse reduction in trade could result in a general shrinkage of a nation's economy leading to adverse economic circumstances such as reduced national income and lack of funds to maintain infrastructure and social services. Since we suggest that government economic policy is likely to suffer from measurement problems, so we assume that it is endogenous. Equation 4 represents the reduced form of the equation for government economic policy, government economic policy depends on country specific income, and our vector of instrument $Z_{i t}$. Therefore we estimate equation 4 and 5 simultaneously. We achieve exclusion by assuming that certain variables (in this case a variable) are correlated with government economic policy in equation 4 but not with life expectancy in equation 5 , allowing us to achieve identification by excluding some variables in equation 5 . We use country investment in stocks as instrument for economic policy, this allows us to conduct instrument correction for economic policy in equation 4.

\subsection{Life Expectancy Model Specification with Government Consumption Spending}

The second variant of the life expectancy specification is shown below, government consumption spending is assumed to be endogenous in equation 7 , so we conduct the

(6.) Gov.Spending ${ }_{i t}=\alpha_{0}+\alpha_{1} X_{i t}+\alpha_{2} Z_{i t}+c_{i}+\mu_{i t}$

(7.) Life. $\exp _{i t}=\beta_{0}+\beta_{1} X_{i, t}+\beta_{2}$ Gov. $\overline{\text { Spend }}$ ling $g_{i, t}+c_{i}+\mu_{i t}$

instrumental correction in equation 6 . Life expectancy depends on government consumption spending and our vector of exogenous variables. Our vectors of exogenous variables $\left(X_{i, t}\right)$ are the logarithm of population, income (GDP per capita) labor market participation, market capitalization rate, foreign direct investment inflow, school enrollment rate, electoral self determination (political stability) exchange rate, inflation and openness. The disposition for increased government consumption spending will depend on a host of factors, its income, and the condition of its economy as well as its political disposition. Therefore if a government sees it citizens as some form of assets that will bring some meaningful economic gains to it on the long-run it will embark on social spending with the aim of getting returns. So we expect government spending to have a positive effect on life expectancy. We assume that government consumption 
spending is endogenous since it suffers from measurement problems since short term payouts such as salary increases and social benefits e.g. subsidies make up government consumption spending and affect life expectancy on the short run. In equation 6, government consumption spending depends on the logarithm of country specific income, and our vectors of instruments $Z_{i t}$. In this case we use health access as instrument for government consumption spending, this allows us to conduct instrumental correction in equation 6 , since we assume that government spending is endogenous.

\subsection{Economic policy and interaction variable institution (policy*institutions}

The third variant of the life expectancy equation is presented in equations 8 and 9 . Including an interactive variable (interact) policy*institutions offers additional opportunity to study the effect institution has on policy effectiveness. Using predictive variables that capture economic policy in our first stage we regressed economic policy on income and stocks of investment and obtain the residuals since economic policy is endogenous, we multiplied the residuals with institutions to get our interaction variable (interact) and use the interaction variable in our second stage this method is known as General Least Square (GLS). Our interaction variable will depend on institutional quality's effect on economic policy this allows us to depict how institutions affect economic policy effectiveness using GLS random effects.

(8. ) policy $_{i t}=\alpha_{0}+\alpha_{1} X_{i t}+\alpha_{2} Z_{i t}+\varepsilon_{i t}$

(9. ) Life. $\exp _{i t}=\beta_{0}+\beta_{1} X_{i, t}+\beta_{2}$ polvc $y_{i, t}+\beta_{3}$ interact $_{i, t}+\varepsilon_{i t}$

\subsection{Instruments}

We explain carefully why our exclusion restriction will hold for our different model specifications. The exclusion restriction we impose on our life expectancy equation is that the instrument should be correlated with economic policy in the first set of equations (equations 4 and 5), government consumption spending in the second set of equations (equation 6 and 7), and economic policy again in the third set of equations where we used two stage GLS (equation 8 and 9) but not with life expectancy. Theoretically this will hold based on the following conditions, if the coefficient for our endogenous variable in our structural equation after imposing the restriction (where we use our instrument as a proxy for the endogenous variable) tends to that in our reduced form equation secondly, if the correlation between the instrument $Z$ and the error term $\varepsilon_{i, t}$ is identically equal to zero as shown below in equation 10.

(10) $E\left|Z_{i, t} \cdot \varepsilon_{i, t}\right|=0$.

This shows that our instrument $Z_{i, t}$ is uncorrelated with the disturbances $\varepsilon_{i, t}$. This stipulates that the only way our instrument is related with life expectancy is only through the endogenous variable and finally, if the exogenous component of the instrument, (the fitted value of the endogenous variable for economic policy and government spending as the case maybe) is uncorrelated with the error term, we can identify the variation in the dependent variable life expectancy (in years) as the slope of coefficient $\beta_{2}$ (see Kraay (2008) for further discussion on exclusion restriction) we depict this in equation 11 below.

(11) $\operatorname{Cov}\left(\right.$ policy $\left._{i, t} \cdot \varepsilon_{i, t}\right) \neq 0$ and $\operatorname{Cov}\left(\right.$ gov. $\left._{\text {spending }} i, t \cdot \varepsilon_{i, t}\right) \neq 0$

This means that $\alpha_{2}$ in not zero therefore life expectancy will vary with changes in economic policy and government spending. Our Instrument should fulfill the above conditions for our exclusion restriction to hold, we explain this further below in a nut shell econometrically as follows. First, our instruments should have a significant impact on the variable they predict. Secondly the instrument should not have an impact on the dependent variable (life expectancy in this case) in the second equation. While often this is tested empirically, Wooldridge (2010) and others have pointed out that this also needs to be done on the theoretical level as testing the impact of the instrument on the dependent variable in the second equation (life expectancy) with a full model could be biased as the instrumental correction has not been made for in the endogenous variable (i.e. economic policy or government consumption spending as the case maybe). We use country specific stock of investment as instrument for economic policy, while we use health access for government consumption spending. Investment in stocks reflects the value that investors place on country stock and the value of stocks at any point in time also reflects the quality of government economic policy. We expect stock of investment to be correlated with government economic policy but not with life expectancy for our exclusion restriction to hold for our first set of equations (i.e. equations 4 and 5). One way to view this is that investors will hold a country's stocks as long as the government maintains stable, sound and consistent economic policies and in cases where a government economic policy is weak, investors are likely to dump such stocks or not invest in such economies. We also expect that a country specific stock of investment will have no direct effect on life expectancy since if government does not have good economic and social policy to reduce factors that are a risk to longevity, gains from investment might not affect life expectancy. 
Therefore the only way through which stock of investment will be related to life expectancy is through government economic policy. This allows us to solve the first and second stage equation simultaneously to overcome the problem of endogeneity, which we associate with government economic policy in equations 4 and 5 . In equations 6 and 7, which is our second specification where we consider the effect of government consumption spending on life expectancy, we use country specific access to health care as instrument for government consumption spending. We expect for our exclusion restriction to hold (in the second set of equations i.e. 6 and 7), that health care access should be correlated with government spending in equation 6, but not directly with life expectancy in our second in equation 7. This will be based on the fact that access to medical care even though if available, is not likely to be free nor easily afforded in many African countries which are characterized with high a population of poor people, so we do not expect that the availability of medical care will lead automatically to increase in life expectancy. The only way through which health access will be related to life expectancy is through government spending, if government creates enabling environment (through its spending) in which people can develop skills at subsidized rate through investment in skill acquisition and training of human capital so that its citizens can become empowered economically (since this could likely lead to job creation), its citizens will therefore have the means to afford health care. Based on these two assumptions we are able to impose our exclusion restriction on our two different model specifications (i.e. the life expectancy models with economic policy and government spending) and argue that our restrictions will hold. We use only one instrument in each case so our model specifications are exactly identified since we have the same number of instrument as endogenous regressor in each case (i.e. for economic policy and government consumption spending). Therefore we do not test the third condition for instrument validity, which is the Sargan over-identification test which is necessary if there are more instruments than endogenous variables being estimated (which is not the case in our analysis).

Good instruments for government economic policy are not easily available. Many economic factors cannot be directly controlled by policy makers however some that can be directly controlled are used in the construction of our economic policy variable, Tinbergen (1978) Asiedu (2006) identified specific factors that influence economic policy such as inflation and trade openness as factors within the control of government and policy makers. Country specific investment in stocks is a good instrument for government economic policy. Since government can for instance decide to set rules regarding the levels of public private ownership within their domain, thereby regulating the amount of the stock of private investment, therefore governments can indirectly determine the degree of economic liberalization present in the economy of a country (see Winters (2004) for further discussion of how governments regulate markets during liberalization reforms). Investment in stocks should be highly correlated with economic policy but not with life expectancy since it is reasonable that the flow of foreign and domestic investment into the private sector will be due investor's perception that there will be continuity in governments sound and consistent economic policies overtime but not related directly with life expectancy. We also expect that government consumption spending should improve welfare and reduce mortality rate. This makes health access a good candidate for instrument for the second specification. Access to healthcare should therefore be correlated with government consumption spending but not life expectancy. One possible way to depict this as stated earlier is the fact that developing countries can experience an increase in the numbers of clinics for instance which could reflective of increased government consumption spending, without necessarily achieving an increase in employment rate so its poor citizens are not likely to afford medical care since it is not free, making availability of healthcare not to have a significant effect directly on life expectancy. Our instruments are highly correlated with our endogenous variables and relevant (see first stage regressions results in Tables 2 and 3 below).

Table 2. First Stage: Economic Policy Regressions

\begin{tabular}{lc}
\hline Method of Estimation & OLS \\
\hline GDP/capita & -0.73 \\
& $(.75)$ \\
Institutional quality & -0.31 \\
Foreign Aid & $(.21)$ \\
& -0.008 \\
Access to Medical Care & $(.05)$ \\
& -0.008 \\
Provision of Social Amenities & $(.05)$ \\
Population & -0.01 \\
& $(.01)$ \\
& 1.59 \\
& \\
\end{tabular}


Exchange Rate

FDI

Labor Market Labor Participation

School Enrollment

Cost of living

$(.001)^{\star \star \star}$

8.55

0.03

70

$\begin{array}{ll}\text { R-Squared } & 0.50\end{array}$

Notes: Coefficients listed with standard errors in parentheses. ${ }^{*},{ }^{* \star}$ and ${ }^{* \star \star}$ refers to significance at the $1 \%, 5 \%$ and $10 \%$ levels, respectively. First stage results in Appendix.

Table 3. First Stage: Government Consumption Spending Regressions

\begin{tabular}{|c|c|}
\hline Method of Estimation & OLS \\
\hline GDP/capita & $\begin{array}{l}-1.17 \\
(.63)^{*}\end{array}$ \\
\hline Population & $\begin{array}{c}0.33 \\
(1.21)\end{array}$ \\
\hline Labor Market Participation Rate & $\begin{array}{l}-0.68 \\
(.35)\end{array}$ \\
\hline FDI & $\begin{array}{l}-0.04 \\
(.04)\end{array}$ \\
\hline Market Capitalization & $\begin{array}{l}0.01 \\
(.01)\end{array}$ \\
\hline Population & $\begin{array}{c}1.59 \\
(1.21)\end{array}$ \\
\hline School Enrollment & $\begin{array}{c}0.003 \\
(.02)\end{array}$ \\
\hline Exchange rate & $\begin{array}{c}0.02 \\
(.01)^{\star \star}\end{array}$ \\
\hline Inflation & $\begin{array}{c}-0.001 \\
(.01)\end{array}$ \\
\hline Openness & $\begin{array}{c}-0.04 \\
(.01)\end{array}$ \\
\hline Political Stability & $\begin{array}{l}-0.12 \\
(.14)\end{array}$ \\
\hline Health Access & $\begin{array}{c}0.04 \\
(.01)^{\star \star \star}\end{array}$ \\
\hline F-Test & 17.99 \\
\hline Chi $^{2}$ (p-value) & 0.00 \\
\hline \# of observations & 52 \\
\hline R-Squared & 0.99 \\
\hline
\end{tabular}

\subsection{Results}

We use fixed effect regression, for the first two specification of our life expectancy equations, since the result of the Hausman test with p-value 0.000 suggest that fixed effect estimation is more appropriate for our model, see Baltagi 
(2005), Baltagi and Wu (2010) and Wooldridge (2010) for further discussion. We include year effect to capture the differences in life expectancy over years. Our results are shown in Tables 4 to 5 . We control for time effect using time dummies for the specification for economic policy and government consumption spending but not for the model with the "interact" effect where we use year because it does not follow a chi square distribution with year dummies. The results of our F-test in Tables 2 and 3 shows that our instruments are highly correlated with the first stage dependent variables respectively. The results in Table 4 show that economic policy has no effect on life expectancy using OLS (with p-value 0.914) and has a negative significant effect on life expectancy using 2SLS after controlling for endogeneity, using investment in stock as instrumental correction for economic policy (with p-value 0.016). This shows the importance of controlling for endogeneity since economic policy might suffer from measurement problems. The results in Table 5 show that government consumption spending has an effect (with p-value 0.014) on life expectancy using OLS and has a stronger effect (with $p$-value 0.000 ) on life expectancy using 2SLS. This shows the reliance of using health access as instrumental correction for government consumption spending, since we assume that government consumption is endogenous. The results in Table 6 show that government economic policy has a negative effect ( $p$-value 0.019$)$ on life expectancy without interacting economic policy with institution. After interacting economic policy with institutions the interactive variable (interact) becomes weakly statistically significant (p-value 0.061 ). This shows that economic policy contributes to a reduction in life expectancy, without the appropriate institutions to execute policies. It is likely that economic policy is not effective due to apathy between the civil service (the embodiment of institutions) and government officials who float economic policies making economic policy not to be contributing in a significant manner to improving life expectancy. Based on the above results we answer the hypothesis that we posed earlier below

- Hypothesis \#1.) Government Economic policy (governments monetary and trade policy) had a negative significant effect on life expectancy. It was likely that economic policy was contributing negatively to longevity in the countries in our sample.

- Hypothesis \#2.) Government Consumption spending (government fiscal policy) had a positive effect on life expectancy. This shows that government consumption spending was likely contributing to increase in longevity since it consisted of welfare spending used in cushioning risk factors to longevity through the establishment of health facilities, provision of social infrastructure such as schools, access to clean drinking water, creating social awareness etc.

- Hypothesis \#3.) Economic policy was found to contribute to longevity in a significant manner when institutional quality was interacted with economic policy. It was likely that institutions were not taken into consideration or bypassed in economic policy implementation. Implementing policies through appropriate channels such as a credible civil service and following due process could lead to a substantial improvement in economic policy effectiveness.

Table 4. Economic Policy Regressions

\begin{tabular}{lcc}
\hline Method of Estimation & OLS & 2 SLS \\
\hline Economic Policy & 0.04 & -2.13 \\
& $(.32)$ & $(.89)^{\star \star}$ \\
GDP/capita & 1.32 & -2.56 \\
& $(1.61)$ & $(1.77)$ \\
Institution Index & -0.11 & -0.24 \\
& $(0.35)$ & $(0.40)$ \\
Foreign Aid & 0.33 & 0.06 \\
& $(.12)^{\star \star}$ & $(.12)$ \\
Access to Medical Care & 0.03 & 0.04 \\
& $(.03)$ & $(.04)$ \\
Provision of Social Amenities & -0.03 & -0.07 \\
& $(.03)$ & $(.03)^{\star \star \star}$ \\
Population & 0.15 & -0.79 \\
& $(.71)$ & $(2.06)$ \\
Exchange Rate & -1.33 & 0.48 \\
& $(.30)^{\star \star \star}$ & $(.32)$ \\
FDI & 0.23 & 0.20 \\
& $(.14)$ & $(.16)$ \\
Labor Market Participation & -0.19 & -0.73 \\
& $(.12)$ & $(.73)$ \\
& &
\end{tabular}




\begin{tabular}{lcc} 
School Enrollment & 0.11 & 0.21 \\
& $(.05)^{\star \star}$ & $(.04)^{\star \star \star}$ \\
Cost of Living & -0.04 & 0.21 \\
& $(.02)$ & $(1.25)$ \\
Instrument & - & Investment in Stocks \\
Chi2 (p-value) & 0.00 & 0.00 \\
\# of observations & 70 & 70 \\
R-Squared & 0.90 & 0.57 \\
\hline
\end{tabular}

Notes: Coefficients listed with standard errors in parentheses. ${ }^{*}$, ${ }^{*}$ and ${ }^{* \star *}$ refers to significance at the $1 \%, 5 \%$ and $10 \%$ levels, respectively. First stage results in Appendix.

Table 5. Government Consumption Spending Regressions

\begin{tabular}{|c|c|c|}
\hline Method of Estimation & OLS & 2SLS \\
\hline Government Consumption Spending & $\begin{array}{c}2.89 \\
(1.08)^{\star \star}\end{array}$ & $\begin{array}{c}3.02 \\
(.62)^{\star \star \star}\end{array}$ \\
\hline GDP/capita & $\begin{array}{c}1.36 \\
(3.24)\end{array}$ & $\begin{array}{c}6.08 \\
(1.34)^{\star \star \star}\end{array}$ \\
\hline Population & $\begin{array}{c}1.33 \\
(2.24)\end{array}$ & $\begin{array}{l}-2.29 \\
(3.13)\end{array}$ \\
\hline Labor Market Participation & $\begin{array}{c}1.0 \\
(.54)^{\star}\end{array}$ & $\begin{array}{l}-1.70 \\
(.60)^{\star \star \star}\end{array}$ \\
\hline FDI & $\begin{array}{l}-0.45 \\
(.27)\end{array}$ & $\begin{array}{l}0.04 \\
(.07)\end{array}$ \\
\hline Market Capitalization & $\begin{array}{l}0.08 \\
(.06)\end{array}$ & $\begin{array}{c}-0.06 \\
(.02)^{\star \star \star}\end{array}$ \\
\hline School Enrollment & $\begin{array}{l}-0.12 \\
(.13)\end{array}$ & $\begin{array}{l}0.05 \\
(.03)\end{array}$ \\
\hline Exchange Rate & $\begin{array}{l}-0.13 \\
(.05)^{\star \star}\end{array}$ & $\begin{array}{l}0.003 \\
(.03)\end{array}$ \\
\hline Inflation & $\begin{array}{l}0.09 \\
(.08)\end{array}$ & $\begin{array}{l}-0.01 \\
(.02)\end{array}$ \\
\hline Openness & $\begin{array}{l}-0.02 \\
(.06)\end{array}$ & $\begin{array}{l}0.03 \\
(.05)\end{array}$ \\
\hline Political Stability & $\begin{array}{c}0.49 \\
(1.14)\end{array}$ & $\begin{array}{c}0.66 \\
(.32)^{\star \star}\end{array}$ \\
\hline Instrument & - & Health Access \\
\hline $\mathrm{Chi}^{2}$ (p-value) & 0.00 & 0.00 \\
\hline \# of observations & 52 & 51 \\
\hline R-Squared & 0.95 & 0.97 \\
\hline
\end{tabular}

Table 6. Economic Policy and interaction with institutions Regressions

\begin{tabular}{lc}
\hline Method of Estimation & GLS \\
\hline Economic Policy & -14.23 \\
& $(5.96)^{\star \star}$ \\
Economic Policy*institutions & 3.08 \\
GDP/capita & $(1.64)^{\star}$ \\
Foreign Aid & 0.70 \\
& $(1.22)$ \\
Access to Medical Care & 0.28 \\
& $(.10)^{\star \star \star}$ \\
Provision of Social Amenities & 0.06 \\
& $(.02)$ \\
& -0.03 \\
\end{tabular}


Population

Exchange Rate

FDI

Labor Market Participation

School Enrollment

Cost of Living

$\mathrm{Chi}^{2}$ ( $\mathrm{p}$-value)

\# of observations

R-Squared
$-0.61$

$(.45)$

$-0.93$

$(.20)^{\star \star \star}$

0.11

(.11)

$-0.09$

(.09)

0.04

$(.04)^{\star *}$

$-0.01$

$(.02)$

0.00

70

0.94

Notes: Coefficients listed with standard errors in parentheses. ${ }^{*},{ }^{* \star}$ and ${ }^{* \star \star}$ refers to

significance at the $1 \%, 5 \%$ and $10 \%$ levels, respectively. First stage results in Appendix.

\section{Conclusion}

In this paper we investigated factors that affect life expectancy in Africa; some questions we asked were, if government economic policy affects life expectancy in Africa? We find that government economic policy has a negative effect on life expectancy in Africa. This showed that economic policy was not contributing positively to longevity. Secondly we also investigated if government consumption spending cushions the factors that are a risk to longevity in Africa? We find that government consumption spending has a positive significant effect on life expectancy, and therefore cushions factors that militate against longevity. We also considered the interactive effect of economic policy and institutions. We find that the variable "interact" has a weak positive effect on life expectancy and contributes to longevity. This showed that channeling policies through appropriate institutions makes economic policies to have an effect on life expectancy. It was likely that government economic policy was weakened due to corruption and circumventing of due process in policy implementation. Our findings show that economic policies in Africa are relatively weak and do not improve the living conditions of people in Africa, making our analogy that only a few people in Africa benefit directly from public goods to be valid. Government consumption spending proved to have a positive impact on longevity, showing that it is likely that welfare spending improves life expectancy in Africa. Institutions we discovered are like pipes that should act as channels for government funds to be geared towards executing programs that can alleviate poverty in Africa, these institutions were either not used (in apathy with economic policies) or are corrupt making them to be like leaking pipes which can weaken policy effectiveness. Executing economic policies through good institutions could lead to useful and effective result for many African countries.

The policy implication of our results is that improving government economic policy (i.e. it's monetary and trade policy) could significantly improve life expectancy in African countries, since economic policy is currently contributing negatively to longevity among African countries. Sound and consistent policies could help create employment and can play a role in the effective execution of public projects that can affect the lives of people living in many poor countries significantly. Reducing inflation and allowing strong private participation in business could rapidly transform many African countries and help reduce mortality rates by economically empowering its indigenous population. Our results are consistent with past literature such as Karl (1997) and Ross (2001), which states that corruption significantly, weakens economic policy in many African countries making such policies to be ineffective in alleviating poverty among their indigenous population. Government consumption spending was contributing positively to longevity, this implies by our results that governments in Africa are likely to continue to spend heavily on consumption. Executing sound policies that could reduce government consumption spending to a sustainable level should be a top priority for many African countries. Empowering people through employment to be able to afford basic social and medical amenities and the establishment of a strong public-private partnership in social and infrastructure development could help reduce government spending on welfare so that this can used for further development programmes. Our results also support reports by World Health Organization 2010 and UNICEF report 2011, that a host of factors are responsible for low life expectancy in Africa this makes government to be overwhelmed with numerous risk factors that reduce longevity leading to huge spending to mitigate such risks which are the causes of high death rate plaguing the continent. 


\section{References}

Ades, A. and Di Tella, R., 1999. Rents, Competition, and Corruption, American Economic Review.

Acemoglu D., (2004) "Root Causes": A Historical approach to addressing the role of institutions in economic development" Finance and Development, 40 (2). 27-30.

Acemoglu, D., Johnson, S. and Robinson, J. A., 2001. The Colonial Origins of Comparative Development: An Empirical Investigation. American Economic Review.

Acemoglu, D. \& Johnson, S., 2007. "Disease and Development: The Effect of Life Expectancy on Economic Growth". Journal of Political Economy vol. 118, pp. 930-88.

Africa Progress Panel Report 2008. "Africa's Development: Promises and Prospects". http://www.africaprogresspanel.org /pdf/2008\%20Report.pdf.

Alesina, A., Devleeschauwer, A., Easterly, W., Kurlat, S. and Wacziarg, R., 2003. "Fractionalization", Journal of Economic Growth, vol. 8, pp. 156-91.

Alesina, A. \& Weder, B. , 2002. "Do Corrupt Governments Receive Less Foreign Aid?" American Economic Review, 92(4), $1129-35$.

Auty R. M. 2001. "Resource Abundance and Economic Development", Oxford: Oxford University Press.

Barro R., 1989 "Economic Growth in a cross-section of countries" Economic Development

Burnside, A. C., \& Dollar, D., 2000. "Aid, Policies, and Growth". American Economic Review.

Canning, D. 2006. "The Economics of HIVIAIDs in Developing Countries: The Case for Prevention". Journal of Economic Perspective.

Dollar, D. 1992. "Outward - Oriented Developing Economies Really Do Grow More Rapidly: Evidence from 95 LDCs from 1976 to 1985" The University of Chicago Press.

Doucouliagos, H. \& Paldam, M. 2008. "Aid Effectiveness on Growth: A meta-study. European." Journal of Political Economy.

Duflo, E., Glennerster, R., \& Kremer, M. 2008 "Using Randomization in Development Economics Research: A Toolkit". Handbook of Development Economics, 4, North-Holland.

Easterly, W. 2005. "What Did Structural Adjustment Adjust? The Association Of Policies And Growth With Repeated IMF and World Bank Adjustment Loans". Journal of Development Economics 76(1), 1-21.

Easterly, W., 2001. "The Lost Decades: Explaining Developing Countries. Stagnation in spite of Policy Reform 1980-1998". Journal of Economic Growth, 6(2), 135-15.

Easterly, W., Levine, R., \& Roodman, D., 2004. "New Data, New Doubts: A Comment on Burnside and Dollar's Aid, Policies, and Growth". American Economic Review, 94(3), 774-780.

Easterly, W. 2009, "How The Millennium Development Goals Are Unfair To Africa", World Development, January 2009.

Easterly W. Drazen A., 2001. "Do Crisis Induce Reform? A Simple Empirical Test of Conventional Reform" By Blackwell Publishers.

Fernandez R. and Rodrik D., 1991. "Resistance To Reform Status Quo Bias In The Presence of Individual Specific Uncertainty" American Economic Review.

Knack S., 2001. "Aid Dependence And The Quality of Governance: Cross Country Empirical Test" Southern Economic Journal.

Lemi A., 2003. "Anatomy of Foreign Aid To Ethiopia: 1960 to 2003" Journal of Economic Literature.

Mehlum, H., Moene, K. and Torvik, R., 2006 "Institutions and The Resource Curse". The Economic Journal.

Miguel E., Mehlum H., Torvik R., 2006. "Poverty Crime In The 19th Century Germany" Journal of Urban Economics.

Miguel E. Gertler P. Levine D., 2005. "Does Social Capital Promote Industrialization? Evidence From A Rapid Industralizer. " Review of Economics and Statistics.

Ross M. (2001) "Natural Resource and Civil War: An Overview of Some Policy Options". Draft For World Bank Conference On The Governance of Natural Resources.

Ross (2001) "Extractive Sectors and the Poor" Oxfam America

Sachs, J.D. and Andrews, 1997 A.M. "Natural Resource Abundance and Economic Growth". Journal of Economic Letters. 